\title{
Materializations of oricha voice through divinations in Cuban Santería
}

Las materializaciones de la voz del oricha en las adivinaciones de la santería cubana

Les materialisations de la voix des orichas dans les divinations de la santería cubaine

\section{Kristina Wirtz}

\section{OpenEdition}

\section{Journals}

Electronic version

URL: https://journals.openedition.org/jsa/15808

DOI: 10.4000/jsa. 15808

ISSN: 1957-7842

\section{Publisher}

Société des américanistes

Printed version

Date of publication: 15 June 2018

Number of pages: 149-177

ISSN: 0037-9174

\section{Electronic reference}

Kristina Wirtz, "Materializations of oricha voice through divinations in Cuban Santería", Journal de la Société des américanistes [Online], 104-1 | 2018, Online since 15 June 2018, connection on 03

September 2022. URL: http://journals.openedition.org/jsa/15808 ; DOl: https://doi.org/10.4000/jsa 15808

All rights reserved 


\title{
Materializations of oricha voice through divinations in Cuban Santería
}

\author{
Kristina WIRTZ *
}

In this essay I explore how oricha (deities') voice is produced in and through Cuban Santería practices that render oricha speech audible, meaningful, and quotable. In the semiotic order governing Cuban popular religious practice, human bodies and other objects can be "activated" as instruments of oricha speech. Divination objects such as cowry shells are understood to be the "tongue" of the oricha, through which the deities and spirits of the dead speak just as surely as when speaking through a possessed devotee or transmitting a message through a human medium. Oricha voices emerge most audibly in divinations and possession speech, although I will argue that the material processes that produce them exceed these specific ritual moments, and that orichas also can speak outside of ritual settings that elicit them. The analysis shows how approaching voice as a material phenomenon, sensible and physical, also activates its potential as a marker of social personhood, agentive force, and even biographical individuality. I trace the qualia of materials themselves and in flows of material substances and interconversions across objects, each contributing their own affordances, to argue for the central importance of transduction or signal conversion across media, and equilibration or the production of equivalences in producing oricha voice. [Key words: voice, materiality, ritual speech, spirit presence, Santería, Cuba.]

Las materializaciones de la voz del oricha en las adivinaciones de la santería cubana. En este ensayo investigo cómo se hace la voz de los oricha (deidades) dentro de, y a través de, las prácticas de la santería cubana que producen esa voz como fenómeno audible, significativo, y citable. En el orden semiótico que rige la práctica popular religiosa cubana, los cuerpos humanos y otros objetos se pueden "activar" como instrumentos del habla de los oricha. Los objetos de adivinación como las conchas de caurí se entienden como la "lengua" de los oricha, y es a través de ellos que hablan las deidades y los muertos tan claramente como cuando hablan por un devoto en trance de posesión o cuando se trasmiten un mensaje a través de un mediún espiritista. Las voces de los oricha surgen más audibles en las adivinaciones y el habla del trance de posesión, aunque también arguyo que los procesos materiales que las producen sobrepasan esos momentos específicos del

* Western Michigan University, Kalamazoo, Michigan, USA [kristina.wirtz@wmich.edu]. 
ritual, y que los oricha también pueden hablar fuera de los contextos rituales que los provocan. El análisis muestra cómo un acercamiento a la voz como fenómeno material, sensible y físico, también activa su potencial como indicador de persona, fuerza agentiva, y hasta individuo biográfico. Ubico los qualia de los materiales en sí mismos y en el flujo de las sustancias materiales e interconversiones entre los objetos, cada uno dando sus affordances, para apuntar la importancia de la transducción o conversión del señal entre medios, y la equilibración o producción de equivalentes en realizar la voz de los oricha. [Palabras clave: voz, materialidad, jerga ritual, presencia espiritual, Santería, Cuba.]

Les materialisations de la voix des orichas dans les divinations de la santería cubaine. Dans cet essai, j'explore la manière dont la voix des (divinités) oricha est produite par des pratiques de la santería cubaine qui rendent le discours des oricha audible, significatif et apte à être cité. Dans l'ordre sémiotique régissant la pratique religieuse populaire cubaine, les corps humains et certains objets peuvent être « activés » comme des instruments de la parole des oricha. Des objets de divination, tels que les cauris, sont considérés comme la « langue » des oricha à travers laquelle les divinités et les esprits des morts parlent tout aussi sûrement que lorsqu'ils possèdent un adepte ou lorsqu'ils transmettent un message à travers un médium humain. Les voix des oricha émergent le plus distinctement dans les divinations et les discours de possession, quoique j'affirme que les processus matériels qui les produisent dépassent ces moments rituels spécifiques et que les orichas peuvent également parler en dehors des configurations rituelles qui les suscitent. L'analyse montre que l'approche de la voix en tant que phénomène matériel, sensible et physique devient également le marqueur d'une personnalité sociale, d'une force agissante et même d'une individualité biographique. Je retrace les qualia (qualités) des matériaux eux-mêmes ainsi que des matériaux dans les flux des substances et des interconversions entre les objets, contribuant chacun avec leurs propres affordances. J'affirme donc l'importance centrale de la transduction ou de la conversion des signaux à travers les médias, et l'équilibrage (equilibration) ou l'émergence des équivalences dans la production de la voix des oricha. [Mots-clés : materialité de la voix, discours rituel, presence spirituelle, santería, Cuba.]

In Cuban Regla de Ocha, also called Santería, practitioners communicate with the deities, called oricha or santos, to receive messages of paramount importance. Through divination and possession of devotees' bodies, the oricha are understood to speak, and their voice is a key form of co-presence as beings whose agency saturates yet exceeds living human experience. Oricha voices complete the "live and direct" communicative circuit that Santería practitioners (santeros) cultivate through ritual practices. ${ }^{1}$ In this ethnographic essay I approach voice as

1. Engelke (2004) describes the idealized model for prophetic communication with the divine in an African Apostolic Church as "live and direct," meaning an unmediated channeling of the Spirit. The expression fits my case well in emphasizing co-presence rather than transcendence. 
a material phenomenon and trace the material practices through which objects, including human bodies, can be "activated" as instruments of oricha speech, within the semiotic order of Cuban popular religious practice.

Although language is sometimes erroneously conceived of as purely referential and symbolic in its semiotic function and therefore not an appropriate focus for a study of materiality, such conceptions say more about the pervasiveness of spirit-matter dualism than about the various dimensions of materiality in language, and in all semiosis. Spoken language, for example, consists of sound waves, which may be ephemeral but which are physically produced and have sensible, measurable physical properties. Harkness (2014) refers to this material aspect of speech as "phonosonic voice." Such sensory qualities, called qualia in Peircean semiotics, have an existence in themselves (what Peirce called the metaphysical condition of Firstness), and in addition come into relationality (Secondness) with other qualia and from there into ever more complex mediated configurations (Thirdness) (Parmentier 1997; Peirce 1998 [1903]). However, as implied by the locus of "qualia" in the subjective, sensory encounter with the world rather than the world itself, there is no direct, culture-free (i.e. nonsemiotic) apprehension of materiality. As Chumley and Harkness (2013) argue, qualia are indexical, and thus already in the realm of Secondness and Thirdness, but we perceive them as material phenomena. What they index is "the feeling of doing" (Harkness 2015, p. 574). Qualia constitute the encounters that materially constrain and afford our situatedness as beings - as feeling objects as well as acting subjects.

As with all speech, oricha voices emerge through their qualia that are knowable only through socio-semiotic mediation, which includes processes of reception as much as production (Bucholtz and Hall 2005; Harkness 2014; Wirtz 2014b). Attending to perceptions and judgments about the qualities of voices helps in tracing how qualia emerging in material practices come to iconize and index social relationalities. My focus here is on the materialization of oricha voices as vectors of divine presence. I will trace these material flows of production and reception as communicative circuits between oricha and their devotees.

While it might be tempting to distinguish voice in the embodied sense from the denotational message it would then seem to carry (to invoke the standard information-theory metaphor), even the simplest communicative circuits involve laminating and crossing modalities: consider how sound waves generated, for example, by muscular sequences in a speaker's vocal tract are received as auditory perceptions of not just what was said, but how, and by whom. We tacitly understand that what was produced has points of similarity as well as difference with what was perceived, although we may still regard what moves through the circuit as remaining the "same" communication. The term "transduction" has come to describe a wide range of such interconversions of information, across fields as disparate as communication, physics, molecular biology, and literary studies. 
In semiotic usage, Keane (2013, p. 9-10) provides the most useful definition of transduction for the current purpose, as "the act of transforming something across semiotic modalities in order to produce or otherwise have effects on power." Influential earlier discussions by Jakobson (1959) on "intersemiotic translation" or "transmutation" and subsequently by Silverstein (2003) on the continuum of translation, transduction, and transformation also emphasize productive movement across sign systems. Such movement requires metasemiotic, meaning reflexive, attention to marking some basis of similarity across some boundary of difference. That is, transduction involves a play of iconicity and indexicality to motivate a connection of likeness across what remain anchored as different sign modalities. I will argue that what emerge through the communicative circuits of Santería as distinctive, quotable messages from the oricha are produced through this transductive play of making equivalences while maintaining distinctions across materially different qualia.

Since the oricha are deities and therefore spiritual rather than material entities, an initial question is: how do the oricha speak, and what do their voices sound like? If, as Harkness (2014, p. 15) argues, voice is "as much body as it is sound," then the most distinctive feature of oricha speech is that it necessarily emanates from other bodies that are not the oricha but that, in the semiotic regime of Regla de Ocha, are "owned" or "claimed" by the oricha while retaining their separate material and biographical identity. We might think of such bodies - both human and other objects - as instruments. And, in fact, "instrument" is the word several of my interlocutors have used in their explanations to me (see also Espirito Santo 2012). The instruments through which the oricha speak include the human vocal apparatus of those they possess during the festive ceremonies that call them into co-presence; the minds of devotees, especially during dreams but also other moments of insight; and the various materials used in three related divination systems. The focus of this paper is on two of these divination systems: the coconut or obi and the cowry shells or diloggún. ${ }^{2}$ In each case the oricha speak through the pattern of casts, in which four coconut pieces or sixteen shells can each fall "mouth up" or "mouth down," and the number landing "mouth up" determine the divination sign and thus which oricha are speaking, to deliver what message.

These communicative instrumentalities - possession, dreams, divination - are also used by spirits of the dead, whose voices santeros carefully work to distinguish from those of the oricha. For their part, santeros (and, for that matter, most practitioners of Cuban popular religion) use modalities such as esoteric ritual speech, prayers, and songs, as well as other sounds, to call upon orichas and spirits, and to initiate or respond to oricha and spirit communications.

2. The most complex system, Ifá, is the exclusive purview of divination specialists called babalawos (see Bascom 1969, 1980; Bolívar Aróstegui 1996; Holbraad 2008; Konen 2013). 
Santeros also engage in interpretive practices, using everyday colloquial language, to make sense of oricha speech. The oricha-santero speech circuit is thus asymmetrical, insofar as orichas and devotees use contrasting communicative modalities that index their different positions as interlocutors. ${ }^{3}$ But for those socialized into santeros' spiritually sensitized semiotic order, oricha speech, which seems in external analysis to be highly mediated and materialized in animating objects and bodies shared with others, is no less live and direct than the face-to-face speech of the living, and is if anything more potent in its world-making capacity. A closer look will show that speech circuits connecting orichas and their devotees fundamentally involve circuits of exchange, flows of substances, and resulting material transformations that constitute the humanoricha relationship (Beliso-De Jesús 2015; Halloy 2013). Oricha speech is but one of these materializations and relies on others.

There is a second major question to consider, which is: how are the disparate "sources" of oricha speech equilibrated? These sources include the different vocal tracts of innumerable different possessed devotees, as well as coconut pieces, cowry shell patterns, and even authoritative texts recording divination results. To equilibrate is to make equivalences, for example by processes of commensuration. So how are equivalences made across heteroglossic resources and multiple, multisensory modalities to enregister a recognizable, even unitary voice of the oricha (Gal 2016; Silverstein 2005)? I approach this question of enregisterment with a novel focus on tracing the productive equilibrations and transductions between different materials with different affordances, shaping what can be received as a divine message. Moreover, oricha voices do not sound in isolation, but partake in circuits of give-and-take, of production and reception, that constitute social relations among orichas and devotees, as dyads and in broader lineages and networks. Any particular circuit of exchange is embedded in long-term, evolving relationships of commitment, requiring ongoing exchange. Thus, although oricha voices emerge most audibly in divinations and possession speech, I will argue that the material processes that produce them exceed these specific ritual moments, and that orichas also can speak outside of ritual settings that elicit them.

This broader perspective invites one further question about the significance of oricha voices within Santería: what does it mean to attribute a voice to the oricha? In part, this is a question about orichas' world-making potentiality, and in part it is a question about the implications for understanding voice, expressly understood as a nexus of agency, distinctiveness, and materiality. In the following section, I discuss two theorizations of voice and how these correspond to the metapragmatic framing of oricha speech in Cuban Santería outlined thus

3. As I have extensively detailed in Wirtz (2005, 2007a, 2007b, 2007c, 2014a). 
far. I then briefly summarize how santeros develop relationships with the oricha, and in particular how they engage the oricha in communicative circuits. Finally, I describe two systems of divination that illustrate the processes of transduction involved in producing oricha voices and their world-making effects.

\section{Theorizing the materiality of voice}

I have already introduced a first theorization of voice that focuses on the qualities of voices as embodied "phonosonic" phenomena mediated by being embedded in social semiosis of the sort I have just described (Harkness 2014). This focus raises questions about vocal production by the oricha, whose instruments - divination signs, for example - may or may not provide a phonosonic source. Even when someone's vocal tract serves as the instrument of an oricha, the physical voice produced is analyzed by other participants as still partly the possessed santero speaking as the oricha. Thus, the embodied voice always necessarily starts out as external to the oricha, until claimed by and ratified as the oricha. So the embodiment of oricha voices highlights a broader ontological principle in Santería of materiality as porous to multiple agencies. Espirito Santo's (2015) superb ethnographic account of mediumship and selfhood in the closely related domain of Cuban Espiritismo details an irreducible multiplicity of "currents" moving through individuals and shaping life trajectories. In this framework, the qualia marking the phonosonic voice reflect the irreducible multiplicity responsible for producing it. And, indeed, the forms of mediation evident in Santería ritual, including the transductions I will describe, tend to multiply the co-presences in interaction, rather than producing unilinear chains between two discrete entities. ${ }^{4}$

This semiotic ideology manifest in the domain of Cuban popular religion resonates with a second theorization of voice: Bakhtin's (1981) dialogical approach, which distinguishes speaking persons, or even their fractionated roles, from voices, such that many voices can emanate from a single "person," just as many speakers may author or animate what is received as the same "voice" (Goffman 1981; Hanks 1996; Irvine 1996). For example, Hill's (1995) classic exposition of dialogicality demonstrates how one speaker, in narrating a story, can deploy different languages, accents, registers, and deictic anchors (indexing times, spaces, persons) to take on many contrasting voices. Through such palpable juxtapositions of social and linguistic qualia, voices may, with varying degrees of recognizability, specificity, social consensus, and markedness, come to represent biographically distinct individuals, social groups, or types, through interdiscursive processes of enregisterment (Agha 2005, 2006).

4. I depart from my earlier analysis of ritual communication (Wirtz 2007c, which emphasized the linearity of genealogical mediations. 
For Bakhtin (1981), voice means sociological perspective, with each voice characterized by its distinct "accent" or set of features (phonological, lexical, etc.) that indexes a history of the sum of prior appearances of those features in other moments of utterance, in dialogical interaction with the expressive intentions of each new speaker who mobilizes a new iteration of those features. The perceived features - qualia - of each utterance thus index an entire interdiscursive web of prior utterances and their sociological perspective(s).

Oricha speech in possession, too, is characterized by a distinctive register that juxtaposes a rustic voice of Bozal, associated with the speech of enslaved Africans, and an esoteric, African voice of Lucumí, as the original African language of orichas, to everyday, colloquial Cuban Spanish (Wirtz 2014a). The qualia of these voices of Bozal and Lucumí - and of the register of oricha speech that, together, they index - are sociological. But notice how any description of what is often described as the rustic, crude, and deformed Spanish of Bozal or the esoteric, divine, African language of Lucumí layers sociological with more directly palpable qualia, thereby allowing our experience of, say, the quality of earthiness in many different sensory modalities to inform how we "hear" earthy speech - that is, a voice we attribute to an "earthy" persona (e.g. a "peasant" or "field hand" voice). The making of such cross-modal equivalences between, say, what earthiness looks like, feels like, sounds like, tastes like across different cases, and in contrast to the look, feel, sound, etc., of, say being refined (as one common antonym), is crucial to the experience of social orders.

A contrasting example is how the "ethereal" character of spirits (in some places, although generally not in Cuba) is often marked by how spirits speakfor example, in high-pitched, whispery or whistling voices (Briggs 1994; Irvine 1982; Schieffelin 1985). It is not that such qualia necessarily or automatically convey ethereality, but that they afford some equilibrations (with similar qualia of wispiness, lightness, ethereality) more readily than others (e.g. qualia of heaviness, largeness, density). For the case of oricha speech in Cuban Santería, the combined qualia of earthiness and esoterism evident in how oricha speak through possessed devotees is echoed in the earthy, organic qualities of coconuts and cowry shells, whose gentle thuds and clicks upon being cast in divination produce esoteric visual signs requiring expert interpretation to be "heard" as oricha speech. ${ }^{5}$

These theorizations are related to the questions of agency and interdiscursivity. Bakhtin's emphasis on how each socially recognized voice conveys its own, separate intentionality resonates with language ideologies in which voice is a manifestation of agency. Depending on the relevant sociohistorical ground, to have a voice can be a metaphor for political recognition; to "hear voices"

5. On the concept of "affordance" in perception, see Gibson (1986). 
can be grounds for rejecting a person's agency. ${ }^{6}$ In Santería's predominant semiotic ideology, voice-as-manifestation-of-agency must be understood as a capacity for action. That is, the shells do not speak for themselves as shells, but serve as instruments to materialize oricha speech as agentive, capable of acting on the world.

To trace the semiotic production of oricha voices is to ask not only about their "actual" manifestation, but also how they are taken up, dialogically, into the heteroglossic voices, practices, and experiences of practitioners, in ways both ordinary and marked, while keeping in mind that oricha voices themselves are heteroglossic. The pantheon of orichas, for example, mirrors the range of human temperaments and identities.

Clearly, the production of oricha voices - and the production of voice more generally - is an interdiscursive phenomenon, requiring semiosis across events, through time and space, and between token and type (Silverstein and Urban 1996; Wortham and Reyes 2015). I reiterate the argument in Wirtz (2007c) regarding the significance of metapragmatic framing of and reflection on rituals-how practitioners anticipate, describe, and interpret, at the time and retrospectively, what is going on. Metapragmatic activity exceeds the "events" of oricha speech it concerns and is open-ended, since further reflections and re-framings can emerge at any time, and anticipatory metapragmatic activity begins to frame future, potential events. And so I explore the mechanisms of interdiscursivity in producing voice, focusing in particular on the temporalities indexed by voices in tandem with other objects. Oricha voices, I suggest, simultaneously index distinctive ritual time-spaces and religious genealogical-historical trajectories. ${ }^{7}$

Rather than the fragmentation and segmentability of "voice" under heteroglossia, our focus is on how those multivocalities are composed into what we can perceive as cohesive, coherent, and distinct voices. This is a question of equilibrating the very different "source" material taken, variously, from possession-speech, divination signs, and dream-reports, as different instantiations of the same authoring voice. Then, too, the oricha sometimes speak as an undifferentiated whole, reported as "the saint says ...," and sometimes as individual oricha, or even the distinctive oricha of a particular santero: not just Obatalá, but Mayenye's Obatalá (see, e.g., Capone 1999, p. 35). Thus equilibration, rather than erasing differences, may highlight inherent multiplicities in what can be recognized as instances of the "type"-in this case, oricha speech.

6. As Johnson (2011) argues, spirit possession's Atlantic World genealogy is entangled with efforts to deny Lockean "forensic personhood" and thus political rights to colonized and enslaved populations. See also Bauman and Briggs (2003).

7. See Wirtz (2014a) on voice and chronotope. 


\section{The relationships between santeros and their oricha}

The relationships among santeros and oricha are the context in which oricha speech materializes. Initiated santeros are religious experts who cultivate authorized relationships of devotion to a particular oricha as their principal oricha. They follow an elaborate, highly reflexive, and codified set of practices that distills some broader principles that are evident across the wide spectrum of Cuban popular religious practices, among other categories of experts and lay participants alike (see especially James Figarola 1999). These principles can be briefly described as follows, regarding the questions of intimacy between initiates and oricha, materializations of oricha-human relationships, ritual hierarchy and kinship, and an ontology of multiplicity in agency.

Santeros cultivate a relationship of intimacy with the oricha said to "own their head," who is "seated" there through the intensive initiation process of ritual rebirth. ${ }^{8}$ It is the oricha who chooses the devotee as his or her "child," and devotees often describe themselves as the child of their principal oricha, lovingly obedient to their "mother" or "father."

Although most of the initiation ceremonies are the privileged secrets of initiates (which I am not), they centrally involve the parallel consecration of both the initiate — and especially the head, as locus of divinity in the body — and sacred objects that also embody the oricha received by the initiate. Most important among those sacred objects are smooth stones generally collected from a river or beach and called otanes (the number depend on which oricha) and the set of polished, flattened cowry shells or diloggún that is consecrated as the "mouth" of each oricha. The consecrated objects, thus, model the place of the human devotee, as a material being in relationship to the oricha who claim that person. ${ }^{9}$

Initiation also activates hierarchical relationships, not only between oricha and devotees but also in the ritual lineages of santeros in relation to one another. Significantly, it is the consecrated stones of the godparent that "give birth" to the oricha-embodiments of that santero's godchildren, forging a material connection across generations in a particular ritual house. Those connections are

8. This oricha is one of the two dozen or so oricha that are recognized in Cuba, of which about a dozen are most frequently received, meaning ritually linked to the initiate during initiation. Each oricha is an archetypal figure with multiple "paths," as well as a biography, domain of the natural world, and preferred offerings, as related through a large corpus of oral literature. See Bolívar Aróstegui (1990) and Sandoval (2006).

9. The consecrated objects are usually kept together in a vessel also dedicated to that oricha and are the materialization for "feeding," "refreshing," and "charging" the oricha. Santeros often call on and refer to these materializations by the name of the oricha they belong to, or collectively as "my saints." This is true of the diloggún as well when these are taken out and prepared for a divination. The initiate's body, and especially his or her head, undergoes the same or similar ritual manipulations (Brown 1996, 2003; Flores-Peña and Evanchuck 1994). 
recognized in the invocations or moyuba that accompany all ritual acts (see Wirtz 2007c). That is, ritual genealogies and ties of kinship that emphasize hierarchy and equivalence are instantiated through both materials and utterances.

Initiation thus creates an irreducible triad of equivalences between oricha, devotee, and consecrated objects such as the stones and diloggún. These triadic relations model how the material entities, both human and object, are and are not the oricha; they simultaneously embody the oricha and remain separate entities owned by the oricha and in relation to one another. The oricha's presence in its material embodiments is both a permanent state of possession in the sense of ownership and a more temporary achievement of co-presence, for example through possession in the sense of seizing control.

The initiation triad and ritual lineage model human bodies and nonhuman objects as always already saturated by a multiplicity of agency — not just oricha, but other kinds of spirits, whether personified or understood as forces and influences beyond human agency. My interlocutors at times used the idiom of "currents," such as the spiritual currents that electrify Beliso-De Jesús's (2015) ethnography of Santería and Espirito Santo's (2015) ethnography of Cuban Spiritism, or in the "little pinches" of bodily sensations and life events that are interpreted as co-presences delivering messages (Wirtz 2007c, p. 83; 2013, 2014 b). As modalities of embodied connection, these transmission circuits are communicative between different forms of agency and constitutive of what Espirito Santo describes as the project of personhood for Cuban popular religious practitioners.

The analogizing of embodied person to personified object is everywhere in Ocha practice, modeling the ways in which the oricha, and, indeed, all of the spiritual world, saturate our material experience with agency manifest in their potent action on our material experience. For example, I once gave a white shawl to an oricha, as part of my offerings during a festive ceremony that I sponsored. My godfather had me wait until the senior santera we had hired to attend was possessed by her (highly regarded) oricha, Obatalá. When we led Obatalá into a back room to be re-dressed in her preferred outfit of a white slip and dress, Obatalá indicated that I should drape the shawl over her head, much as one places decorative cloth over the vessels containing each oricha on an altar. She was for a moment the very image of such a vessel on the altar. Later the shawl was placed on her altar, its movement connecting her head and the consecrated stones, both possessed by Obatalá.

Consider now how a santero explained to me, very early on in my fieldwork, the process by which santeros who are preparing to "crown" a new initiate must ask the stones they collect to "make" each oricha whether they will work:

These, too, have their ceremony. The stones come from the river or ocean. But not all the stones work. Stones are collected from the river and ocean. Now, to make, 
know whether that stone will work for the saint, it's necessary to do a ceremony for them. The stones are brought and then for each one, you pay homage to the saint and ask it, "Are you Yemayá?" You throw the coconut shell. Remember that it is the coconut shell that asks. "Are you Yemayá?" "No." This one won’t work. You do it with another: "Are you Yemayá?" "Yes." Ah, this one works for Yemayá. And so on with each one. The saint that has one, that carries just one sole stone, like Eleggua, like Agayú. One takes a stone and says to it, "Are you Agayú?" "No." This one won’t work. "This one is Agayú?" "No." Confirmed. "Are you Agayú?" "Yes." "Ah, this one is Agayú."10

There is a mystery as to which agency is receiving and answering these questions that I would like to maintain, rather than attempt to resolve. Religious practitioners recognize that everything is infused with animating spirits: not only stones, but when plants are collected for ritual use, a small offering should be left to the plant's "spirit"; even the waste produced by ritual action is spiritually charged and the divination coconut must be asked where it is to be tossed in order to discharge that spiritual potential safely (Wirtz 2009). Witchcraft, Ifá divination, and practices of Regla de Palo alike are predicated on materializations of spiritual agency, for example in powders, amulets, and other powerobjects (Holbraad 2012; James Figarola 2006; Ochoa 2010; Routon 2010). Those agencies include not only the diffuse and ever-present spirits, such as those that are attracted to each object, but also oricha co-presences. So one could also say that it is both the stone and its little bit of oricha-divinity that are asked whether an oricha will accept the stone, with all of its spiritual charges, as its own, or whether there are spiritual incompatibilities: "Can you [stone] be Agayú?" Through the ceremonies of consecration, the accepted stone, together with a bricolage of other stones and objects, will be spiritually charged to simultaneously stand for and materially be (manifest) the oricha to which the assemblage is dedicated, much like the initiated devotee to whose lifelong care the consecrated stones are given.

Moreover, in being consecrated as the oricha and continually manipulated and hailed as such, a spiritual agency is recognized as perceivable in and intrinsic to those objects, which are anything but inert. Even the qualia of a particular stone on the beach already participates in that stone's initial selection to be addressed directly: something about the object calls for the santeros' attention. And a condition of aliveness is highlighted by such routine practices as "feeding" one's "saints," which describes both the material offerings made to the sacred objects and the accompanying "charging" of the oricha itself with that force called aché. Rather than retreat to a dualistic account in which the material actions somehow facilely represent the imperceptible spiritual charging, I suggest that religious practitioners learn to sense both, always in relationship to the other.

10. Translation from Spanish, recorded in Santiago de Cuba, September 9, 1998. 


\section{Calling the orichas}

The previous section's examples also illustrate that the orichas partake in communicative practices in which they not only speak but also respond, meaning that in addition to sending messages, they perceive messages directed to them. Crucially, for all participants in these circuits, communication is not somehow separate from materiality, but often proceeds through material mobilizations and transformations that may accompany speech or may in themselves constitute speaker turns, which is to say crucial links in communicative circuits. Viewed in terms of communicative circuits, offerings to and even festive ceremonies for the oricha constitute bids to respond, as well as being activators of the spiritual potency needed for oricha to act (see Barber 1981).

Consider first the laminations of verbal and material exchanges that Keane (1997) describes (for an unrelated ethnographic case) as fixing one another's communicative function. For example, festive drumming ceremonies (generically called bembé) involve not only drumming, with its rhythms directed to particular oricha, but also the songs accompanying those rhythms, which also call upon particular oricha, either directly addressing them or making reference to some characteristic or story associated with them. Even more than praise, skillfully detonated insults pique the attention of the oricha, such as obliquely referring to an embarrassing story or praising another oricha in competition with the one being hailed. A ritual lead singer demonstrates skill by skating the thin edge of danger in his or her improvised lines, as well as by managing the overall sequencing of songs and energy level of the music and other participants. That is, even beyond the lyrics themselves, more palpable dimensions are important, such as the volume and tempo of the music and the density of sonic textures produced not only by the interlocking drum rhythms, but also by people clapping and shouting, by the added ringing of bells (when the "mother" drum is shaken, so that the cascade of brass bells attached to the largest drum head sounds), and by similarly direct measures of enthusiastic participation in the ceremony. Such features together constitute the effort to attract the oricha's attention.

Similarly, the invocations and prayers that initiate all ritual activity are necessarily accompanied by, and embedded in, material offerings that range from the most durable accoutrements of altars and sacred vessels to permanent gifts (such as decorative cloth, bells, bottles of alcohol, and statues), to more perishable offerings (such as cooked and baked foods, fruits, flowers, animal blood and organs, and fresh water), and even to such ephemera as a lit candle, smoke from a cigar, or a fine mist of rum sprayed from someone's mouth. The choices are always in keeping with a particular oricha's preferences, for example for particular kinds of foods or colors of cloth. Sounds, too, are material offerings as well as hailings. They include not only the full-fledged sequences of songs 
and rhythms in a festive ceremony, but also the more frequent ringing of a particular bell or shaking of a rattle to salute a particular oricha when approaching the altar. Ochún prefers a bronze bell, while Eleggua responds to the rattle of a seed-filled gourd. And here the transfer of qualia across modalities is evident: the bronze material corresponds to the clear metallic sound it produces, just as the more rustic material of a rattle produces a "rougher" sound. These qualities correspond to the qualities attributed to the oricha: Ochún, being refined and elegant, loves materials that have that quality (gold, bronze). She alone among the oricha is best pleased by the offering of violin music, as a distinctively refined sound in contrast to all the orichas' passionate attention to percussion, with its distinctly different acoustic properties.

Approached in terms of their qualia, these material offerings highlight the qualia of speech and song in their phonosonic materiality: it is not only their referential content (which in any case may be opaque to many ritual participants), but also the ways in which their qualities are layered in with other material offerings to constitute a multimodal hailing of the oricha and bid for phatic connection that appeals to multiple senses and channels that humans and oricha alike share. Oricha speech, then, is one form of response in such two-way circuits of communication, and the next section's focus. Oricha may also respond materially and nonverbally, by acting on events or by provoking visions and dreams in devotees. But such visions and events become publicly interpretable as denotational, quotable "messages" from the oricha only by entering into communicative circuits maintained by cycles of richly materialized phatic connection between devotees and oricha.

\section{How the obi and diloggún speak in divination}

To more closely consider the semiotics of divination, I describe use of the coconut and cowry-shell oracles. In divinations, the answer to my question of how the oricha speak is that they have a minimal phonosonic presence, in the muffled sound of shells cast upon a reed mat or clattering on a table. Instead, these materials respond to questions by forming visual signs in patterns of coconut or cowry shell tosses. So the focus shifts to my second question, regarding how the material affordances of these sources undergo processes of transduction and equilibration to convert visual signs into quotable speech.

\section{Using the obí (coconut) for divination}

Consider first a coconut divination, said to be the simplest and most frequently used of divination methods in Ocha and thus a distillation of divinatory logics. The coconut divination is generally described as a source of relatively quick "yes/no" answers, for example to open or ratify a ceremony and to check that offerings are accepted. 
To prepare for the divination, a coconut is broken into pieces, and five pieces of the shell are shaped into approximately disc-like shapes. One of these pieces is set aside as the necessary "witness," while the other four are thrown to land in one of five possible patterns of "up" (white inside showing) or "down" (husk side showing). Each of these five possible signs has a name and standard meaning, canonically like this:

\begin{tabular}{|c|c|}
\hline O O O O (four white side up): & alafia, or "it is good" \\
\hline O O O X (three up and one down): & itagua, or "something is missing" \\
\hline O O X X (two up, two down): & melleife, or "yes, good" \\
\hline O X X X (one up, three down): & okana-sodde, or "it is bad" \\
\hline X X X X (four white side down): & olle-ikún, or "the dead speak" \\
\hline
\end{tabular}

For the three-up, one-down result, the diviner's practical response is to interpret this sign as a "maybe," and to throw the coconut shells again for a confirmation. For the four-down possibility, some santeros told me its meaning was "the grave is open," and this result was taken to be an unambiguously ominous sign of problems, as well as a firm "no" or "not acceptable." The three-down, one-up result also is interpreted as "no" to the question asked and/or as a warning that there is something the oricha do not approve of - for example, perhaps a necessary ritual step was inadvertently skipped or there is some unidentified problem requiring further ritual work. Upon receiving (and naming) this result, santeros proceed to "investigate" (as they say) with further questions and throws of the coconut. These further questions are discussed and formulated with care among the santeros who are present before being directed to the oricha as the obi are cast, since the answer given is taken as definitive and binding, even for questions later judged to have been ill advised. They may take a persistently negative response as reason to call for a diloggún divination, to make a fuller investigation.

\section{Using the diloggún (cowry shells) for divination}

Each santero typically uses the set of cowries consecrated to his or her principal oricha and kept with the vessel containing the oricha's consecrated stones on the santero's altar. ${ }^{11}$ Santeros describe the diloggún as the "tongue of the oricha" and also specify that their diloggún belongs to their particular principal oricha, but that through that oricha, any other oricha can speak.

In the divination event itself, no particular question is verbalized at the start, although the divining santero may hold the cowries in cupped hands up to

11. Santeros use the cowries dedicated to each of the other orichas they receive to address each oricha during a major ceremony such as the itá divination of their initiation or after a "feeding." 
his or her own mouth or to the mouth of the client receiving the divination to whisper a question or problem.

After a series of invocations, prayers, and other preparations to cast the diloggún, which may or may not include the whispered question, the sixteen shells are gently allowed to fall from the diviner's hand onto a table or mat, producing their distinctive clicks as they are shaken together and land. This sound indexes that the oricha have spoken but nothing more: the visual pattern provides the actual message. And so, once cast, the number of shells landing "mouth up" are counted. That number, one to sixteen, is called out by its Lucumí name or oddún - an initial transduction from visual to verbal sign. Eleven of the possible results are "major" signs and five are "minor" signs. Through each sign, one (or more) different oricha are said to "speak." For example: five cowries "mouth up" is the most minor sign (oddun), Oche, through which the oricha Ochún "speaks." Results of thirteen or more cowries up are said to "belong" to the oricha Orula (or Orunmila) and to require that the client seek out an Ifá divination, since Ifá is "owned" by Orula.

Once the first result is established, and assuming the resulting sign is less than thirteen, the diloggún divination proceeds with a series of additional throws of the cowries and also the introduction of a second set of divination objects. Called the $i b o$, these objects include a small dark-colored stone, a round land-snail shell, a large round seed, a piece of white, chalky cascarilla (made from eggshells), and a bone piece or even small head of a doll. The ibo indicate which spiritual agencies are responsible for communicating a particular message through divination, whether the oricha or the dead, and conveying positive or negative forces. Note how the properties of these relatively standardized, small objects index these agencies: meaningful contrasts of color (light and dark), natural or human origin, and properties such as hardness and smoothness motivate what these objects index, even though they are similar in size and shape (iconizing their equivalence to one another as tokens in what Werbner [2016] calls the microdrama of divination).

The client hides a pair of these ibo objects at a time, one in each hand, and the sign of each diloggún or pair of casts, major or minor or a doubled number, like 3-3, determines whether the left or right hand's object is chosen. That result, evident in the object in the client's open hand, will be transduced into a statement about who is speaking, the dead or the oricha, whether they bring a good or bad sign, or whether the answer to a question is "yes" or "no." Diloggún divination thus produces a much larger corpus of possible sign combinations that cannot be as straightforwardly read as a yes or no answer to a single question, but rather convey an overall report on the state of affairs for the client. Once the signs produced through these series of casts have been read, the santero elaborates an interpretation for the client that draws upon the santero's command of the substantial canon of divination proverbs, stories, and other specialized 
information and knowledge of the client's situation. The interpretation moves from naming the signs to indicating which oricha or other spiritual agencies are speaking, and proceeds with ever greater specificity to apply these results to the client's life situation (health, relationships, work, problems, etc.), giving specific advice about any changes needed, further rituals, offerings, and other steps to take.

Having thus overviewed the actual techniques of conducting obi and diloggún divinations, I now identify a few of the key processes of transduction and equilibration that produce and ratify oricha voices, providing ethnographic examples.

\section{Equilibrations of multiple agency in the oracles}

The first semiotic principle I will discuss is equilibration via establishing iconicity between oricha and divination tools, such that the cowries and coconut shells are the mouth of the oricha. Equilibration highlights similarities as the basis of establishing indexical connections between (groupings and motions of) things and multiple spiritual forces. To illustrate, consider the obi: The coconut itself is treated as an entity infused with spirit - personified as Obi and closely identified with the oricha Elegguá in the corpus of parables santeros tell about the orichas - and its inherent multiplicity is materialized in how the whole coconut is first ritually prepared (by washing, for example), then broken into pieces that, as a collective of autonomous yet connected, even interchangeable, parts, become the oracle. The same multiplicity-in-unity is evident for the diloggún as a unit of sixteen cowries. In both kinds of divination, the santero gently throws (or drops) those pieces, a motion away from the santero's body that also is a diagram (iconic) of distancing the result from the santero's agency and introducing other forces.

At its most abstract, this action iconizes the more general circuit of communication-through-exchange, in which the devotees provide the physical activation of the oricha's very ability to participate, and to reply. In turn, the signs are interpreted as the oricha (collectively or as individuals) speaking through the oracle, Obi, and its "owner," Eleggua, and thus enacting the principle of mediation as one transductive process.

\section{Mediational participation framing of orich a voices as co-present interlocutors}

A different angle on the materialization of multiple co-presences is evident in a participation frame analysis of divination (Goffman 1974), through which voices are differentiated by participant role, even as a message is transduced through mediated sequences of questions and responses. Most importantly, the diviner and divination oracle serve as mediators between the client's questions and oricha answers. Consider the following typical metapragmatic account of how a coconut divination works, drawn from the same interview with a santero 
early in my fieldwork as my earlier example (when my evident inexperience best elicited these kinds of normative accounts). ${ }^{12}$ I have organized his account according to three voices - his narration, the hypothetical speech of the godfather carrying out a divination, and the hypothetical speech of oricha answering through the $o b i$ - in order to highlight the imagined dialogue the santero presents in describing how and why a coconut divination might be done to prepare for a small purification ceremony.

The narration presents, in miniature, the participation framing of a divination:

\begin{tabular}{|c|c|c|}
\hline Narrating voice & $\begin{array}{l}\text { Godfather-hypothetical } \\
\text { reported speech framing }\end{array}$ & $\begin{array}{l}\text { Oricha-hypothetical } \\
\text { reported speech framing }\end{array}$ \\
\hline \multirow[t]{5}{*}{$\begin{array}{l}\text { 1. I might have problems at } \\
\text { work. I might myself have } \\
\text { health problems. For this } \\
\text { reason a limpieza [purifi- } \\
\text { cation ceremony] must be } \\
\text { done for me. }\end{array}$} & & \\
\hline & $\begin{array}{l}\text { 2. And the godfather says, } \\
\text { "ok, that's fine. A limpieza } \\
\text { must be done for you. Ok. } \\
\text { Let's ask the coconut now, } \\
\text { 'with whom must we do } \\
\text { this limpieza for you?", }\end{array}$ & \\
\hline & $\begin{array}{l}\text { 3. So, he goes, gets the } \\
\text { coconut pieces, invokes } \\
\text { [moyuba] the saint, } \\
\text { Eleggua, and says, "for-, } \\
\text { with whom must this lim- } \\
\text { pieza be done?" "With you } \\
\text { [Usted], Eleggua?" }\end{array}$ & \\
\hline & 4. He throws. & $\begin{array}{l}\text { 5. What Eleggua says, } \\
\text { "No." }\end{array}$ \\
\hline & $\begin{array}{l}\text { 6. "With you [Usted], } \\
\text { Ogún?" He throws, and } \\
\text { that's how he goes asking } \\
\text { each of the saints. }\end{array}$ & \\
\hline
\end{tabular}

The santero first reports what the godfather, or santero caring for an uninitiated godchild (like me), might say. He has the godfather address the imagined godchild or client, further embedding the question the godfather proposes to ask of the oricha: "with whom must this limpieza be done?" The santero then

12. Translated from Spanish, recorded interview, September 9, 1998. 
describes an outline of the divination itself: the gathering of the coconut oracle and ritual invocation of the oricha, and in particular the oricha Eleggua, as owner of the coconut oracle and thus the one initially addressed through it.

Once properly addressed and appeased (with Lucumí prayers and cool water), Eleggua can then "open the way" to mediate messages from other oricha who can be addressed by name, like Ogún. Notice that the divination itself is represented as a mediated dyadic conversation, or rather as a series of mediated dyadic exchanges: the santero mediates between client and oracle; Eleggua mediates between the oracle and the rest of the oricha. The santero calls a question along the lines of, "with whom must this limpieza be done? With you, Eleggua?" then tosses the coconut pieces, and an answer is reported: "No." The next question then is called and the coconut pieces are again thrown, to produce another response. That is to say, santeros describe a coconut divination as producing a readily voiced, readily quotable, succinct series of human questions and oricha answers.

Notice, too, that this normative account models the necessary transduction of a pattern of shell-up/shell-down coconut pieces cast on the floor between the santero and the altar containing the oricha into words ("yes," "no," "maybe"), but only lightly: "he gets the coconut pieces ... he throws." We barely hear them fall. There is such a complete equilibration of a coconut sign to a quotable voice saying "yes" or "no" that the transduction of "results" into oricha speech seems automatic, incontrovertible, and almost mathematical in how visual signs equal words.

We can now see that these transductions of coconut sign to voice are similarly calibrated in my earlier interview excerpt regarding how stones are chosen for consecration at a santero's initiation. The stones are asked through the obi, meaning that the same participation framing of mediated questions and responses provides what is readily "heard" to be a succinct, incontrovertible "yes" or "no."

\section{Mediation and authorization reach beyond the divination event}

Divinations thus unfold through ritual participation frames that bring oricha voices in divination signs into interactional co-presence. Divinations are also embedded in and forge links between past and future actions in ongoing communicative circuits connecting oricha and devotees. This interdiscursivity, I have suggested, is materialized through transductions that authorize and interpret oricha voice.

Events of divination involve preparatory action, including the assembling of necessary materials and the ritual invocations of orichas, ancestors, and elders in the lineage of any santero who is participating. The series of offerings and invocations, moreover, constitute a diagram of hierarchies of authority (as an 
axis of differentiation) and equivalences between categories of participant and material objects. For example, after lighting a candle in the corner for the spirits of the dead, the santero would recite the moyuba invocation of the ritual lineage ancestors, then greet each oricha in the proper order with a Lucumí song or prayer while shaking their preferred rattle or bell, always directing such action toward the particular oricha's embodied form in a vessel on the altar. Only then, with the entire hierarchy activated into co-presence, would ritual attention turn to the divination oracle itself.

Prayers and invocations, accompanied by multiple offerings ranging from pinches of coconut to ringing bells, sprays of rum, and puffs of cigar smoke, function to activate interdiscursive chains of authorization that point back to "baptismal" moments such as the divining santero's own initiation and the ritual genealogies ratifying those originary and all subsequent ritual events (see Agha 2003). And the ritual genealogies themselves, materialized in the Lucumí-register invocations that accompany every ceremony, point back to foundational "baptismal" moments in Ocha's history in Cuba and, even, ancestral Africa, thereby weaving ever-denser interdiscursive webs of authorization. ${ }^{13}$

By anchoring a particular ritual event's authorization beyond the event itself, the results of the ritual, too, can implicate past and future activity beyond the ritual. For example, to close a drumming ceremony, the most senior santero in attendance will prepare a coconut oracle to ask each oricha on the host's altar to confirm their satisfaction with the ceremony. At the end of a bembe that I sponsored at my godfather's house before departing from fieldwork in Santiago de Cuba in May 2000, one of the results came up okana, negative. The next question was whether the result applied to me, as the ceremony's sponsor: "yes." After further discussion, confirmed with further throws of the coconut, the santeros announced that I needed an (expensive and elaborate) ceremony before my departure from Cuba. Since I was leaving so soon, I put it off. Two days later, at the airport, my flight was inexplicably canceled. My godfather, at my side at the check-in counter, turned to eyeball me with a significant look: see? The oricha had foretold of this problem with my departure. My travails with the airline were thus recontextualized as the predicted continuation of a communicative circuit with the oricha that I, too, was now thoroughly implicated in. Every santero has a stock of similar narratives of how the oricha shape events so as to deliver such "little pinches."

Notice, too, how the mediated participation framing of the divination was repeated at the airport: a santero who had witnessed my ritual results mediated

13. Although not without their share of political controversy, about which see Brown (2003) or any other ethnographic account of Santería, since these controversies are, for better or worse, a favorite topic of non-Cuban ethnographers, this author included. And see Palmié (2013) on scholars' collusion in the creation of authorizing genealogies. 
the oricha's message in my canceled flight as connected to those results, and thus as yet another modality of the oricha speaking to us. Witnessing is a key participant role and a functional element in entextualizing instances of oricha speech so as to render them durable, portable messages. The final two subsections consider these two approaches to witnessing as transductive.

\section{Witnessing as an anchor for transduction}

Rather than being a single role fulfilled by a single participant, witnessing is multiplied across objects, bodies, and agencies that participate in a ritual, as one kind of mediation that produces oricha voices and ratifies their authoritative reach beyond the ritual event.

I have mentioned that the participation framing of both coconut and cowry divination involves a necessary role of "witnessing" that models what is expected in any major ritual work, such as for initiation: namely, that members of the broader community of practitioners be formally invited to witness and thus be able to ratify that a ceremony was carried out properly and accepted by the oricha. The ritual invocations of orichas, ancestors, and living members of one's ritual lineage acknowledge these agencies as at least potentially co-present during rituals, and thus as witnesses. All participants, and particularly those specifically invited as witnesses, are links in chains of authorization that extend back in time and out across the religious community to anchor what transpires in any particular ritual as part of a larger community of Ocha (even when, as I detail in Wirtz [2007c], that community defines itself as much through controversy and differing interpretations of ritual events as through consensus). Indeed, the formalization of witnessing ensures that major rituals will enter into intertextual circuits through which they will be remembered, including in holding members of the religious community accountable to oricha speech.

The divination tools themselves subdivide into shells that are cast and shells that witness the cast. For the obí, recall that of its five prepared shell pieces, four are cast and one is set on the mat before the altar as the witness. And there are more cowries in a set than are actually cast: most oricha receive eighteen cowry shells, but only sixteen (diloggún is abbreviated from merindiloggún, meaning "sixteen") are cast, with the remaining shells serving as "witnesses." These, like the human witnesses, are material reminders of the gravity of oricha speech.

\section{Transduction of oricha speech into writing}

In diloggún divinations, an additional form of witnessing is the written record made of divination results in the santero's notebook, a notebook begun during initiation to record the all-important oddún or signs (mentioned in a quoted excerpt above) that result from the initiatory itá (from méta, referring to the third day of initiation) divination ceremony. Conscientious santeros - certainly all 
the santeros I ever saw do diloggún divinations - record the sequence of signs that result from casting the cowries, their canonical names, and any resulting prescriptions, such as offerings or necessary ceremonies, that they interpret based on those results. The act of writing a divination result down is yet another transduction, from oral to written form, producing yet another equilibration across different forms of "communicative" materiality.

Hierography, as Dianteill and Swearingen (2003) call it, spans the most informal jottings of notes to oneself to the most formal and closely guarded records a santero might maintain in a notebook throughout his or her career, even to be inherited by godchildren (León 1971). And there is continuity, too, between jottings in pencil or pen and the ritual "writing" of "signs" in powder and chalk that is also part of popular religious practice (Holbraad 2012; Martínez Ruiz 2005). As Otero (2018) details, such writings convey different degrees of permanence and vary from very detailed to maddeningly partial, but all can be taken up as inscribed oricha speech.

For example, in one diloggún consultation I received, the wife of the diviner recorded a summary of what he said upon seeing each result, writing in his notebook that my sign was $6-8$, or Obbara-Unle. She continued recording the next series of casts, including the santero's spoken transduction of results depending on which ibo the casts selected, and writing a summary of the words the santero spoke in looking at each result. Her resulting transcription, as I copied it into my fieldnotes, presents a succinct summary diagram:

6-8

Obara Unle

4, 7-6, 11-7, 5-6

con Iré arikú yale

The last phrase summarizes my luck as good fortune (iré) from the spirits of the dead (ikú, in the phrase arikú yale, which indicates a result good enough to require no further ritual action). That is, a reading of visual signs produced a spoken summary of who was speaking and what they said, which then was written down in this spare form, as the most literal representation of the diloggún results. In this case, the written inscription was almost mathematical, producing a set of equivalences (equations!) between sign results and their names as if writing a mathematical proof.

This result is then rendered as oricha speech. The oricha Changó is most closely associated with Obbara, and the canonical proverb associated with my result, Obbara Unle, is "ears do not surpass head; respect your elders" (orejas no pasa cabeza, respeta a sus mayores; see Angarica [n.d.] or any print or online guide for santeros for quite consistent examples). Not knowing me well, the santero told me that I was probably a child of Changó and delicately inquired whether I already had a godfather in Ocha and whether he knew I was 
getting consultations with others, this being frowned upon even in the interest of good ethnography. He also saw the oricha Eleggua speaking through my sign and drew upon another canonical proverb, "it is the head that carries the body," to tell me:

Eleggua says that (he) brings iré with Iroso [4] and arikú he brings with Oddi Obbara [7-6] and moyare Ojuani Oddi [11-7, which must also have been a result]. Eleggua says that you were born to be the head. That you were born to be an intellectual, a person capable of deepening whatever knowledge or desires for that knowledge, isn't it true? Your own interest, isn't it, in how to arrive at the thing so that afterward you will know all the steps that you want to make, now it won't have any doubt, true? ${ }^{14}$

As with the coconut divination examples, notice how seamlessly visual signs, together with their canonical associations, are transduced into writing and speech attributed to the oricha: "Eleggua says ..." And this first part of the divination's message is also where Lucumí, the tongue of the oricha, is most heavily used. But notice, too, the progression from incontrovertible message that can only be attributed to the oricha to what we can recognize as interpretation, shot through with the santero's own efforts to explain the results as they apply to me, his unfamiliar client. Here lies the genius of the good diviner, as my interlocutors would say (see also Werbner 2016), on whom responsibility for interpretation falls. But the transition from quoted oricha speech (itself produced through the transductive processes I have pointed out) to santero's interpretation has no sharp boundaries. Heteroglossic, its dialogicality becomes more apparent as the santero checks his interpretation with me (and I surely backchannel with thoughtful nods in response).

In this final example, I have emphasized the entextualizing role of transducing divination results into a written record that also witnesses, and anchors, further transductions into the fleshed-out interpretation of what those results mean.

\section{Conclusion: equilibration and transduction in the production of oricha voices}

When oricha speak through possessed devotees, similar processes are evident in how the oricha are first hailed into presence, how mediating hierarchies of authorization and witnessing as well as equilibrations between different modalities of oricha presence are mobilized, and how the oricha's actual productions - audible speech produced by the vocal tract of the possessed-require further sequences of transduction and equilibration of material events and movements to make their authority and significance apparent, while allowing interpretation to remain open-ended. Space does not permit a full exegesis of

14. Translated from Spanish, recorded divination-consultation, September 2, 2000. 
possession speech (but see Wirtz 2014a). Crucially, divination and possession speech are often expressly linked into communicative circuits, as when an oricha speaking in a possession mentions a previous divination result or is invoked in a subsequent divination. And such communicative circuits, as we have seen, exceed the moments of oricha speech they produce. Whether sourced as divination signs, possession speech, the canonical and often esoteric ancestral wisdom of songs and proverbs, or stories from the divination corpus, these heteroglossic resources are knit together, referred to, reiterated, and interpreted into unmistakable voices of the oricha, delivering messages that devotees ignore at their peril.

To conclude, I highlight four key angles of my analysis of the materializations of oricha speech through communicative circuits via the semiotic transformations of transduction and equilibration.

First, I have addressed the initial question of how the oricha speak, and what they sound like, to describe not only the audible sounds of speech, but also the multimodal communicative circuits through which such speech becomes audible and attributable to the oricha. What is understood as the "source" is phonosonic in the case of oricha speech through possessed devotees, but in divination it is visual "signs" produced by casts of the coconut or cowry shell oracles that are then given voice by santeros as quotable oricha speech. In both cases, the sources must be authorized as consecrated instruments of the oricha. Just as important as these sources are their transductions into quoted, interpreted, inscribed, and commentated speech, whose possibilities for circulation appear limitless, so long as ritually framed moments continue to be indexed as the ultimate, authoritative sources. The processes by which these originary signs - human voices and collections of objects - are interpreted into divine messages can also extend to interpreting dreams and visions and diverse events (e.g. delayed flights and other moments of good or bad luck). Any of these can then be recognized, usually retrospectively, as the oricha speaking through such material effects. A multiplicity of mediations produce transductions of such events into reportable oricha speech, which is pulled into interdiscursive relationship with other events of divination or possession speech.

Second, my analysis demonstrates the more general point that voice is an accomplishment, requiring techniques of production and mediation to emerge. As part of the combined phonosonic and dialogical approaches to understanding "voice" highlighted in my analysis, I have emphasized the key role of interdiscursive processes and showed that these involve an entire catalogue of material flows via transductions. Examining the semiotic production of oricha voice requires us to examine the participation framing of rituals not in isolation, but as focused, highly reflexive, and multimodal events that index interdiscursive genealogies and enact ideologies, including of multiplied agency, material correspondences, and mediated relationality between oricha, persons, and objects. In this way, 
what transpires in rituals (and the discourse surrounding them) models the kinds of relations possible among entities, be they people living or dead, objects that are anything but inert, and spiritual agents that infuse the material world.

Third, what best characterizes the voice of the oricha is that they speak through material things - bodies and objects - that, while claimed by the oricha, remain themselves at the same time. And in so doing, oricha speech emerges in recognizable types, always imbued with an authority that exceeds human agency. In this sociogenic and cosmogenic semiosis, oricha voices are not isolates, nor are they event-level phenomena. Rather they emerge into social recognizability at the interdiscursive level, through processes that bring differing modalities of communication and heteroglossic voicings into juxtaposition, accomplishing differentiation, equilibration, and coherence, even amid disagreements over interpretation. At the heart of the matter is a recognition of the fundamental multiplicity constituting any entity or form of agency. The oricha always speak through multiple things brought into relation with one another: consider that the divination oracles themselves are multiple and in relation to one another as oracles and witnesses, and whose manipulation produces the "microdramatics" of elaborating and interpreting divination signs. Oricha speech always emerges in dialogue, modeled as communicative circuits of hailings and responses, questions and answers. Consider, too, that santeros who undergo initiation have their very bodies equilibrated to other objects - stones, shells, and so forth - that are simultaneously consecrated to the oricha, in part by being brought into genealogical connections and mediated hierarchies with other persons and objects. That is, processes of equilibration, based on recognizing similarity, also rely on productive differentiation, for example between different kinds of material entities: stones and shells may be lifelike in some ways, but not others; human bodies may be object-like but cannot be completely reduced to objectstatus; and orichas act in the world but exceed any particular materialization. Equilibrating objects, bodies, and agencies links them without reducing their productive differences, and thus highlights fundamental ontological mysteries in just what constitutes life, agency, and power.

Finally, I have highlighted the central importance of two semiotic processes: transductions that allow communication to cross between media and materials, and equilibrations that selectively highlight equivalences between media and materials, by recognizing some qualia or perceivable qualities in common across other dimensions of difference. Given how multimodal the sources of oricha speech are, and given how heteroglossic even their most evidently phonosonic realizations are, equilibrations allow oricha speech to be recognizable and interpretable despite its diverse manifestations.

I have also traced some of the various transductions and mediational participation framing through which oricha voices can emerge. These semiotic processes - the work of ritual experts - function in a broader semiotic ideology 
in which heteroglossic voicing and materialization of multiplicities iconize irreducible multiplicity even in seemingly unitary persons and objects (which turn out to manifest the influences, even co-presence, of many agencies). Mediation, too, is evident everywhere in the metapragmatic framing of all ritual communication and its embedding in an entire social cosmology of relations-across ritual lineages and hosts of spiritual presences, including but never limited to the oricha. Even a santero performing a divination alone or for a single client calls upon that host of co-presences to witness and authorize the oricha and spirit communications that result, and these seem to emerge inevitably through chains of mediation, like the relays of electrical circuits. Oricha voices, then, are in themselves spiritual corrientes, evident in communicative circuits that traverse diverse material effects and can even be materialized as quoted speech. *

* Manuscrit reçu en septembre 2017, accepté pour publication en mars 2018.

Acknowledgments - Foremost, I thank all of my Cuban interlocutors over the years for their patient help, especially my dear friends Ernesto Armiñán Linares, María Isabel Berbes Riveaux, A. Abelardo Larduet Luaces, and Nurina Salas Rivera, and all Santiago's omolocha. I am grateful to Katerina Kerestetzi for the initial encouragement, and to her, two anonymous reviewers, Mélanie Deniaux, and the JSA editorial committee for excellent revision suggestions, which I have incorporated as best I can. Special thanks to Amanda Weidman and my fellow "Conduits of Voice" workshop participants at Bryn Mawr: Danny Fisher, Christopher Fraga, Laura Kunreuther, and Perry Sherouse.

\section{References cited}

Agha Asif

2003 "The social life of cultural value", Language and Communication, 23, p. 231-273.

2005 "Voice, footing, enregisterment", Journal of Linguistic Anthropology, 15 (1), p. 38-59.

2006 Language and social relations, Cambridge University Press, Cambridge.

Angarica Nicolas Valentin

n.d. Manual de Orihate. Religion Lucumi, unknown, Cuba.

BAKHTIN Mikhail M.

1981 The dialogic imagination. Four essays, Caryl Emerson and Michael Holquist (trans.), University of Texas Press, Austin.

BARBER Karin

1981 "How man makes god in West Africa: Yoruba attitudes towards the Orisa", Africa, 5 (3), p. 724-745.

BASCOM William R.

1969 Ifa divination. Communication between gods and men in West Africa, Indiana University Press, Bloomington. 
Kristina WIRTZ

BASCOM William R.

1980 Sixteen cowries. Yoruba divination from Africa to the New World, Indiana University Press, Bloomington.

BAUMAN Richard and Charles L. BRIGGS

2003 Voices of modernity. Language ideologies and the politics of inequality, Cambridge University Press, Cambridge.

Beliso-De Jesús Aisha

2015 Electric Santería. Racial and sexual assemblages of transnational religion, Columbia University Press, New York.

Bolívar Aróstegui Natalia

1990 Los Orichas en Cuba, Ediciones Unión, UNEAC, Havana.

1996 Ifá. Su historia en Cuba, Ediciones Unión, Havana.

Briggs Charles L.

1994 "The sting of the ray. Bodies, agency, and grammar in Warao curing", Journal of American Folklore, 107 (423), p. 139-166.

BRown David H.

1996 "Toward an ethnoaesthetics of Santería ritual arts: the practice of altar-making and gift exchange", in Arturo Lindsay (ed.), Santería aesthetics in contemporary Latin American art, Smithsonian Institution Press, Washington, p. 77-146.

2003 Santería enthroned. Art, ritual, and innovation in an Afro-Cuban religion, University of Chicago Press, Chicago.

Bucholtz Mary and Kira Hall

2005 "Identity and interaction. A sociocultural linguistic approach", Discourse Studies, 7 (4-5), p. 585-614.

CAPONE Stefania

1999 La quête de l'Afrique dans le Candomblé. Pouvoir et tradition au Brésil, Éditions Karthala, Paris.

Chumley Lily Hope and Nicholas Harkness

2013 "Introduction: QUALIA", Anthropological Theory, 13 (1-2), p. 3-11.

DianteILl Erwan and Martha SweAringen

2003 "From hierography to ethnography and back: Lydia Cabrera's texts and the written tradition in Afro-Cuban religions", Journal of American Folklore, 116 (2), p. 273-292.

ENGELKE Matthew

2004 "Text and performance in an African church. The book, "live and direct", American Ethnologist, 31 (1), p. 76-91.

ESPIRITO SANTo Diana

2012 "Imagination, sensation and the education of attention among Cuban spirit mediums", Ethnos, 77 (2), p. 252-271.

2015 Developing the dead. Mediumship and selfhood in Cuban espiritismo, University Press of Florida, Florida. 
FloREs-PeÑa Ysamur and Roberta J. EvanchUCK

1994 Speaking without a voice. Santería garments and altars, University of Mississippi Press, Jackson.

GAL Susan

2016 "Scale-making. Comparison and perspective as ideological projects", in Scale: discourse and dimensions of social life, University of California Press, Berkeley, p. 91-111

GiBson James J.

1986 The ecological approach to visual perception, Lawrence Erlbaum, Hillsdale (NJ).

GoFman Erving

1974 Frame analysis, Harper and Row, New York.

1981 Forms of talk, University of Pennsylvania Press, Philadelphia.

Halloy Arnaud

2013 Objects, bodies and gods. A cognitive ethnography of an ontological dynamic in the Xangô cult (Recife, Brazil), in Diana Espirito Santo and Nico Tassi (eds.), Making spirits. Materiality and transcendence in contemporary religions, I.B. Tauris, London, p. 133-158.

HANKS William F.

1996 "Exorcism and the description of participant roles", in Michael Silverstein and Greg Urban (eds.), Natural histories of discourse, University of Chicago Press, Chicago, p. 160-202.

HARKNESS Nicholas

2014 Songs of Seoul. An ethnography of voice and voicing in Christian South Korea, University of California Press, Berkeley.

2015 "The pragmatics of qualia in practice", Annual Review of Anthropology, 44 (1), p. 573-589.

HiLl Jane H.

1995 "The voices of Don Gabriel. Responsibility and self in a modern Mexicano narrative", in Dennis Tedlock and Bruce Mannheim (eds.), The dialogic emergence of culture, University of Illinois Press, Urbana, p. 97-147.

HolbraAd Martin

2008 "Definitive evidence, from Cuban gods", Journal of the Royal Anthropological Institute, 14, p. 93-109.

2012 Truth in motion. The recursive anthropology of Cuban divination, University of Chicago Press, Chicago.

IRVINE Judith

1982 "The creation of identity in spirit mediumship and possession", in David Parkin (ed.), Semantic anthropology, Academic Press, London, p. 241-260.

1996 "Shadow conversations. The indeterminacy of participant roles", in Michael Silverstein and Greg Urban (eds.), Natural histories of discourse, University of Chicago Press, Chicago, p. 131-159. 
Kristina WIRTZ

JAKOBSON Roman

1959 “On linguistic aspects of translation”, in Ruben A. Brower (ed.), On translation, Harvard University Press, Cambridge (MA), p. 232-239.

James Figarola Joel

1999 Los sistemas mágico-religiosos cubanos. Principios rectores, UNESCO, Caracas.

2006 La Brujería Cubana. El Palo Monte, Editorial Oriente, Santiago de Cuba.

JoHnson Paul Christopher

2011 “An Atlantic genealogy of "spirit possession", Comparative Studies in Society and History, 53 (2), p. 393-425.

Keane Webb

1997 Signs of recognition. Powers and hazards of representation in an Indonesian society, University of California Press, Berkeley.

2013 "On spirit writing: materialities of language and the religious work of transduction", Journal of the Royal Anthropological Institute, 19 (1), p. 1-17.

KonEN Alain

2013 “'Ilé Tuntun’ à La Havane. Une réinterprétation de l'ancestralité africaine et de la divination Ifá", Ateliers d'anthropologie [on line], 38, http://journals. openedition.org/ateliers/9395, consulted 06/07/2018.

LEÓn Argeliers

1971 "Un caso de tradición oral escrita”, Islas (Santa Clara), 39-40, p. 139-151.

Martínez Ruiz Felix Bárbaro

2005 Kongo Machinery. Graphic writing and other narratives of the sign, Ph.D. dissertation, Art History, Yale University.

OcHOA Todd Ramón

2010 Society of the dead. Quita Manaquita and Palo Praise in Cuba, University of California Press, Berkeley.

OTERo Solimar

2018 "Residual transcriptions. Ruth Landes and the archive of conjure", Transforming Anthropology, 26 (1), p. 3-17.

PALMié Stephan

2013 The cooking of history. How not to study Afro-Cuban religion, University of Chicago Press, Chicago.

Parmentier Richard

1997 “The pragmatic semiotics of cultures", Semiotica, 116, p. 1-42.

PeIRCE Charles Sanders

1998 [1903] "Harvard lectures on pragmatism", in Peirce Edition Project (ed.), The essential Peirce, Indiana University Press, Bloomington, p. 133-241.

RouTON Kenneth

2010 Hidden powers of state in the Cuban imagination, University Press of Florida, Gainesville. 
SAndoval Mercedes Cros

2006 Worldview, the Orichas, and Santería. Africa to Cuba and beyond, University Press of Florida, Gainesville.

SCHIEFFELIN Edward

1985 "Performance and the cultural construction of reality", American Ethnologist, $12(4)$, p. 707-724.

Silverstein Michael

2003 "Translation, transduction, transformation: Skating glossando on thin semiotic ice", in Paula G. Rubel and Abraham Rosman (eds.), Translating cultures. Perspectives on translation and anthropology, Berg, Oxford, p. 75-105.

2005 "Axes of evals. Token versus type interdiscursivity", Journal of Linguistic Anthropology, 15 (1), p. 6-22.

Silverstein Michael and Greg Urban

1996 "The natural history of discourse", in Michael Silverstein and Greg Urban (eds.), Natural histories of discourse, University of Chicago Press, Chicago, p. 1-20.

WERBNER Richard

2016 Divination's grasp. African encounters with the almost said, Indiana University Press, Bloomington.

WIRTZ Kristina

2005 “"Where obscurity is a virtue.' The mystique of unintelligibility in Santería ritual", Language and Communication, 25 (4), p. 351-375.

2007a "Enregistered memory and Afro-Cuban historicity in Santería's ritual speech", Language and Communication, 27, p. 245-257.

$2007 b$ "Making sense of unintelligible messages in divine communication", Text and Talk, 27 (4), p. 435-462.

2007c Ritual, discourse, and community in Cuban santería. Speaking a sacred world, Gainesville, University Press of Florida.

2009 "Hazardous waste. The semiotics of ritual hygiene in Cuban popular religion", Journal of the Royal Anthropological Institute, 15, p. 476-501.

2013 "Spirit materialities in Cuban folk religion. Realms of imaginative possibility", in Diana Espirito Santo and Ruy Blanes (eds.), The social life of spirits, University of Chicago Press, Chicago, p. 126-156.

2014a Performing Afro-Cuba. Image, voice, spectacle in the making of race and history, University of Chicago Press, Chicago.

2014b "Spiritual agency, materiality, and knowledge in Cuba", in Paul C. Johnson (ed.), Spirited things. The work of "possession" in Afro-Atlantic religions, University of Chicago Press, Chicago, p. 99-129.

Wortham Stanton and Angela Reyes

2015 Discourse analysis. Beyond the speech event, Routledge, New York. 
